\section{Light-sensitive Cells}

A

PAPER read before the Royal Society of Arts on April 6 by Dr. F. H. Constable gives an interesting account of light-sensitive cells in the service of man. Such cells may be divided into three classes, (1) photo-conducting cells which change their resistance on exposure to light, (2) photoelectric cells which emit electrons, and (3) photo-voltaic cells which exhibit the Becquerel effect. The last-named are electrolytic cells in which an electromotive force is created when either the electrolyte or an electrode itself is exposed to illumination. To these classes might now be added a fourth, illustrated by the modern cuprous oxide cell, which generates an electromotive force without the presence of an electrolyte. In this type the surface separating the oxide from the supporting copper plate seems to play an important part in the action, and recent theory would indicate the existence of a 'potential wall' at this surface.

After describing various forms which the lightsensitive cells may take, Dr. Constable discussed the practical applications of such cells. The intensity of full moonlight measured by a photo-cell is about 0.2 lux, the unit of measurement (lux) being the light intensity 1 metre from a standard candle, while full starlight is of the order of 0.0002 lux in intensity.

One interesting application of the photo-cell is in the measurement of light intensity during the strong illumination of the day and during twilight. Over the period of a year there is very little seasonal variation in the minimum brightness at the time of sunset, while a certain amount of increase in the maximum values is noticeable in the summer and autumn months. It would appear that the principal factor which controls the intensity at dusk is the cloudiness of the sky. Rapidly moving clouds can produce very striking sudden irregularities in the brightness of the sky.

Circuits containing selenium cells may be used for turning lights on or off with the coming on of darkness and dawn. Other interesting applications mentioned are for race timing, apparatus counting, sorting, and burglar alarms. The use of the photo-cell to obtain good synchronisation in talking films is now a wellestablished practice.

\section{University and Educational Intelligence}

MANCHESTER.-On May 11 the University celebrated the annual Commemoration of Founder's Day by holding a Congregation at which honorary degrees were conferred on Sir James Jeans (Doctor of Science), Dr. W. D. Ross, Lord Rutherford, Sir Arthur Salter, and Mr. W. R. Sickert (Doctors of Laws). The Chancellor, the Earl of Crawford and Balcarres, in his address, alluded to the distinction gained by the University in the award this year of five Royal Society medals, including the Copley medal, to past and present members of the staff. The honorary graduands were presented by Prof. J. L. Stocks, and replies on their behalf were made by Sir James Jeans and Sir Arthur Salter. Sir James Jeans referred to the distin. guished roll of physicists produced by the University; while Sir Arthur Salter, in the course of a discussion of the financial crisis, suggested that the discoveries of science are outrunning man's ability to control the powers they offer, and urged that universities ought to aim at producing men capable not merely of academic but also of administrative distinetion.

The Manchester Municipal College of Technology has issued a prospectus of evening courses of lectures and laboratory work to be held during the summer, commencing May 30. The courses cover various branches of engineering, chemistry and chemical technology, textiles, mathematics, physics, and industrial administration.

THE work of the University of London during 1931-32 is reviewed in the Principal's recent annual report. Growth in the number of students continued steadily both on the internal and external sides, and there was a notable development of university extension work. Candidates for first degrees numbered 3675 and for higher degrees 652 , the corresponding figures for the preceding year being 3543 and 548 . The reconstitution of the University three years ago made possible an integration which has proceeded apace and proved its quality in vigorous reaction to the stress of hard times. The Court, beforehand in appreciating the need for restraint and encouraged by the Government's determination to continue undiminished the payment of university grants, volunteered to forego during the second half of 1931-32 and the whole of the following year ten per cent of the London County Council's maintenance grants, and to postpone claims on its capital grants so far as possible. In the face of a reduction of grants from the Board of Education and local education authorities for extension courses and adult tutorial classes, the Senate yet contrived to reduce the fees it charges for them. Among the checks to progress suffered in consequence of financial stringency were postponements of the development of the geophysics department of the Imperial College and of the construction of the East London College high voltage laboratory. The most momentous single event of the year was, perhaps, the selection of Mr. C. Holden as architect of the University buildings to be erected on the Bloomsbury site. A development involving a most important addition to the central institutions of the University is the transformation, to take effect next September, of the London Day Training College, hitherto a municipal institution, into a University department under the title of the Institute of Education.

Awards of Commonwealth Fund Fellowships tenable by British graduates in American universities for the two years beginning September 1932 include the following: Mr. G. C. W. Allan (Glasgow), to the University of Michigan, in mechanical engineering; Mr. K. E. Boulding (New College, Oxford), to the University of Chicago, in economics; Dr. J. H. Chesters (Sheffield), to the University of Illinois, in metallurgy; Mr. K. C. Dunham (Durham), to Harvard University, in geology; Mr. N. E. G. Hill (University College), to Stanford University, in electrical engineering; Mr. W. A. Macfarlane (Balliol College, Oxford), to the University of California, in physical chemistry ; Miss M. E. Metcalfe (University College, Aberystwyth), to Johns Hopkins University, in entomology ; Dr. J. Pace (Liverpool), to Princeton University, in physical chemistry; Mr. W. C. Price (University College, Swansea), to Johns Hopkins University, in physics; Mr. A. S. Roy (St. Andrews), to the University of Michigan, in physics; Mr. R. M. Shone, (Liverpool), to the University of Chicago, in business administration; Mr. E. T. Stiller (Glasgow and St. Andrews), to the Rockefeller Institute, in biochemistry; Mr. George Tatham (University College, London), to Clark University, in geography ; Mr. D. N. Truscott (Imperial College of Science and Technology, London), to the Massachusetts Institute of Technology, in electrical engineering. The following have been appointed to Fellowships tenable by candidates from the British Dominions : Mr. J. H. Kirk (Natal University College and Cambridge), to the University of North Carolina, 
in social science; Mr. A. Smithies (Tasmania and Oxford), to Columbia University, in economics. The following have been appointed to Fellowships tenable by candidates holding appointments in government service overseas : Mr. D. W. Dodwell (Indian Civil Service), to Columbia University, in economics; $\mathrm{Mr}$. C. J. Joubert (Department of Agriculture, South Africa), to the University of California, in entomology ; Mr. W. M. McNeill (Forest Department, Ceylon), to Yale University, in forestry.

\section{Calendar of Geographical Exploration}

\section{May 30, I580.- The Kara Sea}

Arthur Pet, in the George, accompanied by Jackman in the William, sailed from Harwich to search for the North-east passage. Pet was the first sailor from western Europe to reach the Kara Sea: he separated from Jackman at Vaygatz and the latter and his vessel were lost. On his journey from the Pechora eastwards, he discovered the strait between Vaygatz island and the mainland. Pet's voyage attracted a good deal of interest, and Barents took with him on his last journey a copy of Pet's journal. This was found, along with other books, frozen in among the remains of Barents' wintering on the north-east side of Novaya Zemlya, by the Norwegian walrus hunter, Gundersen.

\section{May 3r, I 869.- Novaya Zemlya}

The Norwegian hunter, E. H. Johannesen, anchored at Mezhdushar Island, whence he sailed up the west coast of Novaya Zemlya in nearly open water. In the following year he circumnavigated the island. For the latter feat he was awarded a gold medal by the Norwegian Academy of Sciences; he had previously received a silver medal for his hydrographical work in the Kara Sea. His voyages and those of Carlsen and of John Palliser upset all previous theories about the state of the ice to the east of Novaya Zemlya. Carlsen's voyage of 1868-69 was of interest because he found on the north-east coast of Novaya Zemlya in $76^{\circ} 7^{\prime} \mathrm{N}$. a house the roof of which had fallen in, and which was filled with gravel and ice. From this frozen gravel were recovered household articles, books, and boxes, preserved perfectly for nearly three hundred years since they were abandoned by Barents in 1597. In 1876 Charles Gardiner, by systematic excavations, discovered many other relics of Barents, including a short account of the most important incidents in the expedition, signed by Barents and Heemskerk. (See also entry for May 30 above.)

\section{June I, I 849.-David Livingstone}

David Livingstone set out across the Kalahari desert and discovered Lake Ngami ; in 1851, while exploring to the north of this lake, he discovered the Zambezi River, the existence of which in this region was unknown. Before he undertook his next journey, Livingstone studied astronomy in order to make his surveys more accurate. His $1852-56$ journey altered completely the conception of the map of Africa. He went up the Liambai, the main Zambezi stream, crossed the Congo basin and reached the west coast at Loanda. Thence he returned to the Zambezi, discovered the Victoria Falls, and followed the river to the east coast, reaching Quilimane in 1856. Thus for the picture of a sandy desert in which rivers lost themselves he substituted a well-watered country, with grassy valleys, much fertile soil and great tracts of forest. He verified Sir R. I. Murchison's hypothesis that the continent presented an elevated plateau, somewhat depressed in the centre, from the sides of which rivers flowed to the sea. A journey in 1858 resulted in the discovery of Lake Shirwa, and in the correction of erroneous ideas about Lake Nyasa. In 1866 he reached the southern shores of Lake Tanganyika, of which Burton and Speke had discovered the northern portion, and in 1867-68 discovered Lakes Mweru and Bangweolo. In October 1871 he met H. M. Stanley at Ujiji and together they explored the north of Lake Tanganyika. Livingstone refused to return with Stanley; he was consumed with eagerness to find the source of the Nile. He reached Lake Bangweolo and died there on April 30, 1830. Livingstone's achievements in African exploration secured his fame; his nobility and humane outlook gained him the warm affection of his countrymen and of the natives among whom he worked.

\section{June I, I 849.- The Great Salt Lake Region}

Capt. H. Stansbury set out from Leavenworth on the Missouri River and discovered a new and shorter route through the Rocky Mountains to Salt Lake City. Stansbury and his assistant, Gunnison, surveyed the deserts to the west of the Great Salt Lake, the coast of the lake itself, and the region between Salt and Utah Lakes. The return journey was made from Fort Bridger, skirting the northern end of the Medicine Bow Mountains and the southern end of the Laramia. Mountains to the North Platte River, a saving of about sixty miles. Besides exploring much new ground and making careful surveys, the expedition collected valuable data about the natural history and geology of the region and brought back accounts of life in the Mormon settlements.

\section{June 2, I773.-Ice Pack North of Spitsbergen}

Capt. C. Phipps sailed with two vessels from the Nore and attempted to find a passage through the ice north of Spitsbergen. Their highest latitude was $80^{\circ} 48^{\prime}$ and they reached $20^{\circ}$ E., examining the edge of the ice for more than $20^{\circ}$ of longitude and finding no opening. Phipps Island was discovered on this voyage. A further exploration of the edge of the ice was made by Buchan and Franklin in 1818, during which they sailed from $10^{\circ} \mathrm{E}$. to $10^{\circ} \mathrm{W}$. but could find no opening.

\section{June 2, I9Io.--North-West Mongolia}

D. Carruthers set out from Kuzhabar, a village on the Russian frontier, to explore Mongolia. He surveyed the upper basin of the Yenisei River, mapping about 1800 square miles, and filling in many gaps. He then explored the Barkul-Hami district. Carruthers had spent 1908 in the western Tian Shan, south of the Naryn River. In 1909 he had travelled in Arabia, reaching Teima by a route west of El Jauf.

\section{June 3, 1870.-Western Borderlands of Arabia}

Joseph Halévy, a Jew of French nationality, arrived in Nejran. This is probably the "Negrana" of Elius Gallus, Eparch of Egypt, whose expedition was described by Strabo. From that time until Halévy's journey, no European had visited it. Halévy travelled in the character of a learned rabbi of Jerusalem, and, setting out in 1869 , crossed Jabel Yam, the highest ridge of the Yemen, and discovered the ruins of Min. Thereafter he crossed the fringes of the terrible Akháf, suffering much, but finally reaching his goal. He returned to Jauf by a more westerly and less desert route, across valleys on the eastern fringe of the Sachan plateau, in which were many ruins. In spite of the fact that his interests were mainly archæological, his extensive journey resulted in geographical knowledge of much hitherto entirely unexplored country.

No. 3265, VoL. 129] 